\title{
ÜZLETI MODELLEZÉS ÉS AZ INTERNETES ÜZLETI MODELLEK
}

$\mathrm{Az}$,„üzleti modell”, amely az internetes vállalkozások felfutásának idején az egyik leggyakrabban használt, de legkevésbé megértett fogalom volt, napjainkban kezd visszatérni a menedzsment gyakorlatába és irodalmi szóhasználatába. A szerzó bemutatja, hogy honnan ered a kifejezés, mitól vált felületessé, és miért érdemes mégis megjegyeznünk. Az üzleti modell az értékteremtés mechanizmusáról rajzol elénk egy rendszert, ezzel a folyamatábráknál átfogóbb nézốpontot képvisel: egy alapvetô múködési logikát, amelyre a szervezet egyedi stratégiája illeszthetố. A modellezés egysége lehet az üzletágnál szúkebb, egy üzleti probléma, vagy tágabb, egy ellátási lánc vagy értékhálózat is. Az üzleti modellezés három fokozat valamelyikével történhet: a szöveges (az eset), a grafikus (a térkép) és a számszerú (a szimulátor) modell más-más felhasználási szempontokat szolgál. A szerzố áttekinti e szempontokat, de az üzleti modellezés gyakori buktatóit is megjelöli. A cikk második része kiemelten foglalkozik az internetes üzleti modellezéssel. Ennek során az értékajánlat, a szervezeti/hálózati modell, a bevétel-költség modell, valamint az infrastruktúra és szabályozási környezet összetevốk mentén mutatja be azon szakirodalmi javaslatokat, amelyekból átgondolt üzleti modellek szerkeszthetốk. Meglátása szerint azonban az internetes üzleti modelleknél sem tekinthetünk el a fizikai folyamatok, a stratégia, valamint számos puha tényezó szerepétól.

Kulcsszavak: üzleti modell, internet, stratégiaalkotás.

Az ezredforduló táján a kezdô internetes üzleti vállalkozások gyors sikere kapcsán a menedzsment-folyóiratok és a gazdasági sajtó egyaránt rátalált az internetes üzleti modellek (e-business models) varázsszóra. A sikerreceptekre éhes közönség elé jól hangzó sémák tucatjait tárta elô a szakirodalom. A vállalkozások látványos tôzsdei zuhanása sem a sémák elvetését hozta, sokkal inkább azzal érveltek az elbukott kezdeményezések boncnokai, hogy az adott vállalkozásnak „,nem volt jó az üzleti modellje”. Napjainkban már az optimistább elemzók is óvakodnak internetes üzleti modellek emlegetéséról, viszont maga az üzleti modellezés (business modelling) témaköre új erőre kapott.

A szakirodalom áttekintésével két kérdésre válaszolok. Ismeretes, hogy az internettel kapcsolatban felvetett új üzleti modellek kevés magyarázatot fúznek a koncepció üzleti modellként való értelmezéséhez. Ezért egyrészt áttekintem, mit nevezünk egyáltalán üzleti modellnek, modellezésnek, milyen szinteken értelmezhetjük ezeket, és mint eszköz, mire használható a vezetés, stratégiaalkotás során. Az internetes üzleti modellekre rátérve másrészt azt vizsgálom, milyen pontokon mutat hiányosságot a szakirodalom ahhoz, hogy valóban modellként tekinthessünk a gyakran idézett internetes koncepciókra. Az üzleti modellezés és az internetes modellek összekapcsolásával olyan eszközhöz jutunk, amely valódi segítséget nyújt egy innovatív üzleti ötlet kidolgozásához és bevezetéséhez - függetlenül attól, hogy az újítás központjában az internet áll-e.

\section{Az értéklánctól az üzleti modellig}

Az üzleti modellezés fogalma az 1970-es években a számítástechnikai, számítástudományi magazinokban, folyóiratokban jelent meg. Stähler (2002) Konczal, illetve Dottore cikkére hivatkozik, akik elsốk között ajánlották a vezetốk figyelmébe a korábban a matematikusok által kedvelt modellezést. A fö üzenet ekkor a szervezet folyamatainak, tevékenységeinek, adatainak és kommunikációs kapcsolatainak modellezésével egy, a napi munkát támogató informatikai rendszer kiépítése volt. Ebbe a vonalba csatlakoztak be a személyi szá- 
mítógép terjedésével a folyamatmodellezó eszközök és a táblázatkezelók. Az elóbbi a folyamatok, adatkapcsolatok összefüggésrendszerének megtervezésében, ábrázolásában nyújtott segítséget. Az utóbbi segítségével viszont a tervezési sémák fősorait alábonthattuk, a részösszetevőkkel teszteket hajthattunk végre, néhány billentyú lenyomásával „mi lenne, ha” típusú elemzések váltak végezhetôvé (Magretta, 2002). Korábban az „üzleti modell” csak a tények után vált világossá, ezekkel az eszközökkel viszont a vállalkozás viselkedése modellezhetôvé vált. Az üzleti modellezés számítástudományban való gyökerezése nem véletlen, hiszen egy adott szoftver rendszerterve, ,,architektúrája” régóta az elemek és a közöttük lévő kapcsolatok kitalálását, leírását jelentette.

Az 1980-as években az üzleti modellezés - az adatés folyamatmodellezés világából - az üzleti folyamatok és a stratégia környezetébe helyeződött. Napjaink üzleti modelljeinek szerzói leggyakrabban Porter (1985) értéklánc-koncepcióját tekintik klasszikus üzleti modellnek. Ez alapvetố és támogató tevékenységeket különböztetett meg, melyek mentén a fogyasztói érték teremtődik, illetve a költségvezetés vagy a megkülönböztetés megvalósul. Hogy ennek ellenére „,a stratégák sokáig nem foglalkoztak az üzleti modellel", az annak tudható be, hogy iparáganként volt egy közismert, általánosan követett modell. Sőt, iparágak felett álló alapvetố jellemzôje volt ezeknek, hogy a vertikális integráció jellemzőit osztották (Tapscott, 2001: 5. o.). Az üzleti modellek napjainkban is a klasszikus értékláncból (értékrendszerből) indulnak ki, a történetmesélés régi hagyományait követve, minden új üzleti modell a ,régi történeteket” variálja (Magretta, 2002). Ebbe a vonulatba sorolhatók a virtuális értéklánc-modellek is, melyek még az internetrobbanás elôtt kezdték hangsúlyozni, hogy az információ és az információtechnológia átszövi a hagyományos értéklánc folyamatait és kapcsolatait (például Rayport - Sviokla, 1995). Az üzleti modell kifejezés más közelítésben új szervezeti-múködési modellként is megjelent. Viscio - Pasternack (1996) amellett érvel, hogy a vállalatot újra fel kell fedezni: az „új üzleti modell” a globális központ, az üzleti egységek, a belsố szolgáltatások és a kormányzás elemeiból áll, melyek között a kapcsolódások vannak. Ez a nézet az üzleti modellezést inkább a szervezés-szervezetalakítás, semmint a célkitúzés és stratégiaalkotás vezetési funkcióhoz kapcsolja (a vezetési funkciókról lásd Dobák, 1996).

Az üzleti modell fogalom használatának az internet terjedése és az új gazdaság irodalmának megszületése adott lendületet. Az 1990-es évek második felében elôször a népszerú üzleti és számítógépes magazinok hasábjain jelent meg, majd felfedezték maguknak az e-business témájára szakosodott tudományos folyóiratok. Az ezredfordulótól kezdôdően az általános vezetési szakirodalom által is kedvelt témává vált. Sorra születtek a legkülönbözóbb felfogásban értelmezhetô internetes üzleti modellek, melyek inkább hallgatólagos értéknövelési modellek voltak, minthogy a mögöttes előfeltevések kifejtése többnyire hiányzott (O'Daniel, 2001). A fogalom népszerúségének gyors felfutása az értelmezés sokféleségét eredményezte. Az ezredfordulóra egyre több szerzố hangsúlyozta, hogy az üzleti modell

- irodalma nem konzisztens, és sokáig híján volt a konkrét meghatározásoknak (Timmers, 1998: 2. o.; Mahadevan, 2002: 55. o; Chesbrough - Rosenbloom, 2002: 532. o.),

- az egyik leggyakrabban használt, de legkevésbé megértett fogalom az internetes üzlettel kapcsolatban (Rappa, 1999: 1. o.),

- egy jól csengố varázsszó, általánosan elfogadott jelentés nélkül (Osterwalder - Pigneur, 2002: 2. o.),

- fogalmát az elemzók össze-vissza említik, mindenfélére használják (Tapscott, 2001: 4. o.),

- gyakran a szerzók homályos eredetú receptje arra vonatkozóan, hogyan kell kinéznie egy üzletnek ahhoz, hogy sikeres legyen (Stähler, 2002: 6. o.).

Nem meglepó tehát, hogy az üzleti modell meghatározására tett kísérletek is sokféle eredményt hoztak. A legfontosabb szakirodalmi meghatározásokat az 1. függelékben foglalom össze. Az ott bemutatott megközelítésekból az üzleti modell fogalmának következő jellemzói rajzolódnak ki:

- az üzleti modell egyszerre rajzol elénk egy rendszert és mesél el egy történetet,

- az értékteremtés logikája, mechanizmusa áll a középpontjában,

- egy architektúra, amely egyrészt a szervezeten, másrészt ellátási láncon belüli folyamatokat és kapcsolataikat, harmadrészt a mozgósított erőforrások összekapcsolását írja le,

- a modellt fenntartó bevételek forrását, áramlását öszszekapcsolja a többi elemmel.

Egyes szerzők ezen túlmenően külön meghatározást kínálnak az új vagy internetes üzleti modellekre. Venkatraman (2000: 18. o.) szerint ezeknél kritérium, hogy „az értékajánlat nagyságrendi és fenntartható növelését kínálja a vevő́knek a hagyományos üzleti modellt követô vállalatokhoz képest" (Venkatraman, 2000:18. o., Lam - Harrison-Walker, 2003: 18. o.) pedig azokat a módszereket, koncepciókat, sémákat és architektúrákat tekintik e-business modellnek, amelyek segítségével a szervezetek az internetet vagy a világhálót a stratégia megvalósítására használhatják. 
Az üzleti modellek a gyakorlatban két szempontból mérettetnek meg: a számok, illetve az elbeszélés tesztje szerint. Azaz, éppen úgy megbuknak, ha az „eredménykimutatás számai nem egyeznek”, mint akkor, ha ,,a történetnek se füle, se farka”. A jó üzleti modell ,egy logikus történetet mesél el, hogy kik a vevőink, mit tekintenek értéknek, és hogyan keletkezik pénzünk ezen értékek nyújtásából" (Magretta, 2002: 90. o.). A teszt nem egyszeri, a piac folyamatosan viszszajelzi, hogy a történet még mindig érvényes feltevésekre épül-e. „Az üzleti modell [azonban] csak akkor áll meg, ha a vevókról alkotott feltételezéseinket józan gazdaságossággal kapcsoljuk össze: ebból kell az eredményt megkapnunk" (Magretta, 1998: 4. o.).

\section{Az üzleti modell és a stratégia}

Az üzleti modell fenti meghatározásának félreértéséból fakadó, az e-business vállalkozásoktól gyakran hallott idézet volt, hogy mostantól nem számít, milyen „üzletben utazunk”, csak az, hogy milyen üzleti modellt használunk (idézi Lam - Harrison-Walker, 2003: 18. o., valamint Applegate - Collura, 2000: 2. o.). „A vállalatoknak nem volt szükségük stratégiára, vagy valamilyen különleges szakértelemre, de még vásárlókra sem; nem kellett más, csak egy internetes üzleti modell, amely a távoli, meghatározhatatlan jövóben óriási nyereséget ígért” (Magretta, 2002: 86. o.). Ezek ,az üzleti tevékenységre és bevételszerzésre vonatkozó laza koncepciók" távolról sem bizonyultak elegendőnek, „hibás gondolkodáshoz és önámításhoz vezettek”. Az iparági környezetben értelmezett értékteremtés, a versenyelôny-szerzés módjának tisztázása nélkül az üzleti modell ,igen gyenge alap” egy vállalat vagy üzletág felépítéséhez - mutat rá Porter (2001: 73. o.).

A stratégia és az üzleti modellezés azonban nemcsak a gyakorlatban, hanem a szakirodalomban is keveredik. Magretta (2002: 92. o.) egyenesen úgy fogalmaz, hogy ,az »üzleti modell« és a »stratégia « manapság az üzleti élet szinte legfelületesebben használt kifejezéseivé váltak. Jelentésüket gyakran a végletekig kibővítik, és mindent értenek alatta, mígnem végül oda lyukadnak ki, hogy semmit sem jelentenek.

A keveredés elsô számú oka, hogy a stratégia és az üzleti modellek egyaránt a „mit?”, a „kinek?” és a „hogyan?" kérdésekre épülnek. Óhatatlanul találunk olyan elméleti ajánlásokat, amelyek átnyúlnak az egyik témakörból a másikba. Markides $(1997 ; 1998)$ stratégiai innováció felfogása rokon az új üzleti modellek szószólóinak megközelítésével, amikor az egy-egy iparág rejtett előfeltevéseivel (,mental modell”) való szakítást figyeli meg a hagyományos piacvezetókkel szemben sikeres kihívóknál. Pateli (2002) és más szerzók üzleti modell meghatározásában másfelól a szegmentáció és a megkülönböztetés témája is szerepel, amelyek túlmutatnak egy általános iparági sémán, és hagyományosan a stratégia érdeklódési körébe tartoznak. Chesbrough - Rosenbloom (2002: 535. o.) pedig a stratégiaalkotás egy speciális esetének tekinti az üzleti modellezést:

- az üzleti modellezés a vevốknek nyújtott értékből vezeti le az értékteremtés valamennyi jellemzójét (,tiszta lap”),

- a tốkefinanszírozás gyakran kimarad belóle („,új vállalkozás"),

- a szervezeti-stratégiai elôzmények által nem befolyásolt (,felszabadult gondolkodás”).

$\mathrm{Az}$ üzleti modellek azonban sokkal közelebb állnak a stratégia megvalósításához, mint a kijelöléséhez (a stratégiai tervezésról lásd Antal-Mokos és szerzôtársai, 1997). Az üzleti modell ott ér véget, ahol a stratégia kezdődik (Tapscott, 2001). Ugyanis, ,az üzleti modellek - mint egy rendszer - azt írják le, hogy miként illeszkednek egymáshoz az üzlet darabkái. Ám nem számolnak a teljesítmény egy igen kritikus tényezójével: a versennyel" (Magretta, 2002: 91. o.). Igaz ugyan, hogy egy nehezen utánozható és az iparág gazdasági viszonyait megváltoztató új modell versenyelőnyhöz vezethet - ilyen volt a számítógépgyártók között a Dell „közvetlenül a gyártótól” modellje -, de az esetek többségében - ahogyan az ,internetes bukások” is jelzik - az üzleti modellt megkülönböztetô stratégiával kell kiegészítenünk (Porter, 2001; Magretta, 2002). Ebbe a felfogásba illeszkedik Osterwalder és Pigneur (2002: 3. o.) megjegyzése, miszerint az üzleti modell ,a hiányzó láncszem a stratégia és az üzleti folyamatok között". Az 1. ábra kiemeli, hogy az üzletimodell-elemeket és azok illeszkedését vizsgálja. A versenyhez való viszonyát a stratégia határozza meg, míg a tényleges múködéshez hatékony üzleti folyamatokra kell bontanunk a modell elemeit. Következésképp, az internetes üzleti modellek sem kész receptek, hanem legfeljebb új lehetôségek, amelyekre - az átalakuló stratégiai környezetet is számba véve - többféle stratégia építhetô.

1. ábra

\section{Az üzleti modellezés a stratégia és az üzleti folyamatok között}

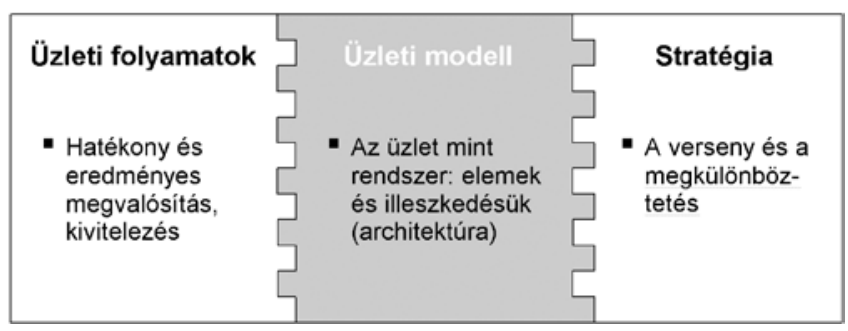


A számos internetes kudarc további tanulsága, amint azt az 1. táblázat ugyancsak mutatja, hogy egy új üzlet indítása során nem tekinthetünk el a részletek kimunkálásától csupán azért, mert az üzleti modell kirívóan ígéretesnek tûnik. Ha a modell egyes elemei mögött rosszul átgondolt vagy gazdaságosan megvalósíthatatlan folyamatok állnak, akkor a jónak túnó modell is elbukik. Az internetes kereskedelemben a készletezés és a logisztika számos esetben bizonyult ilyen kihívásnak.

\section{Az üzleti modellezés alkalmazása}

A szakirodalom alapvetôen három felhasználási irányát különbözteti meg az üzleti modelleknek: a javaslattételt, az általánosítást és a szimulációt (Alt - Zimmermann, 2001). Viszonylag nagy egyetértés mutatkozik abban is, hogy az üzleti modell nem jelent „megoldást”, a siker tudományos levezetését, sokkal inkább a modell adott szituációban való „múködtetése" vezethet sikerekhez (Rayport, 1999). Az üzleti modellek felhasználását ezért a következô területeken remélhetjük (Alt - Zimmermann, 2001; Stähler, 2002; Osterwalder - Pigneur, 2002; 2005; Chesbrough - Rosenbloom, 2002; Magretta, 2002; Shoder, 2003):

- a múködés mögötti feltételezések kinyilvánítása, hogy az alkalmazás során a piac tesztjének vessük alá ezeket,

- a kulcstényezók és -mechanizmusok, valamint ezek kapcsolatának megértése egy adott üzleti területen (,tervezóeszköz”, „összkép”),

- az üzlet értékelésében releváns mutatók azonosítása és alakulásuk követése,

- a meglévő üzleti modell megváltoztatási és fejlesztési lehetôségeinek azonosítása a változás elôsegítése érdekében, vagy befektetési döntések megalapozása,

- kockázatmentes szimuláció (kísérletezés, tanulmányozás) és tanulás ebből,

- a menedzsment támogatása adott üzlet lényegének és a kialakított értelmezésének érintettek felé történő kommunikálásában,

- az információrendszerek értékalkotásban betöltött szerepének meghatározása.

Az üzleti modellezés során az elemzés egysége többféle lehet. Kézenfekvő, hogy egy üzletágat (vagy új kezdeményezést) állítsunk a középpontba, annak mögöttes logikáját, ezáltal érzékenységét, életképességét vizsgálva. Ilyenkor az értékteremtő folyamatok, mechanizmusok, és az ezekhez hozzájáruló résztvevók szerepe hangsúlyos. Az üzleti modellezés ugyanakkor jól használható egy konkrét üzleti probléma szintjén is, a komplex helyzetben szerepet játszó tényezók (gyakran természetes mutatók, például kapacitás, teljesítmény) azonosítására. A modellezés rávilágíthat a tényezók között olyan „ördögi körökre”, amelyek korábban a probléma megoldását hátráltatták. Az üzleti modellezés egysége lehet az üzletági szintnél magasabban is, egész szervezetek, sốt végsố fogyasztókat kiszolgáló szervezetközi értékhálózatok múködésének elemzésére. Több iparágban is megfigyelhetô a hagyományos értékláncok jogilag független szervezetekbe való szétbomlása (részletesen lásd Evans - Wurster, 2000), miközben a végsố fogyasztó szempontjából továbbra is a korábbi, immár önálló vállalatokból álló üzleti modell határozza meg az értéket. A 2. ábra az üzleti modellezés elemzési egységének e három szintjét foglalja össze: a szintek eltérô elemekból építkeznek (balra), és a vizsgálatok fókusza is más hangsúlyt kap (jobbra).

\section{2. ábra}

Üzleti modellezés különböző szinteken

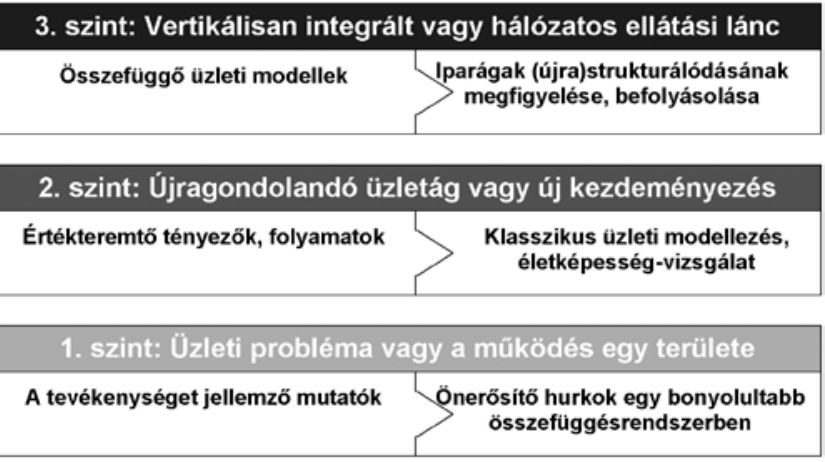

Az elemzés egységétól függetlenül is igen különbözó típusú üzleti modellekkel találkozhatunk a gyakorlatban. A különbség fóként a kifejtés módjában, a bemutatás jellegében rejlik. Itt az üzleti modellezés három fokozatáról beszélhetünk. A fokozat nem jelent fázist, azaz szükségszerúen egymást követô lépéseket, viszont mindegyik fokozathoz eltérô felhasználási terület említhetô (1. táblázat). A szövegesen kifejtett, „kvalitatív” üzleti modellek elsôsorban ötleteket tudnak adni. Az üzleti modell grafikus bemutatása az adott helyzet, azon belül pedig ok-okozati kapcsolatok megértését segíti. A számszaki összefüggéseket tartalmazó formalizált modellektól a kísérletezés, szimuláció lehetóségét remélhetjük: a modell egyes tényezókre való érzékenységének vizsgálatát, vagy különböző forgatókönyvek tesztelését.

I. fokozat: az eset. A vállalati esettanulmányok jó ideje - körülbelül egy évtizede Magyarországon is - meghatározó elemei a menedzsmentiskolák oktatásának. A módszertan arra épül, hogy a vezetók általá- 
Az üzleti modellezés fokozatai

\begin{tabular}{|l|l}
\hline I. fokozat: \\
Az eset
\end{tabular}$\quad \begin{aligned} & \text { II. fokozat: } \\
& \text { A térkép }\end{aligned} \quad \begin{gathered}\text { III. fokozat: } \\
\text { A szimulátor }\end{gathered}$

\begin{tabular}{|l|l|l|l|}
\hline Jellege & - Szöveges & - Ábrázolt & - Számszaki \\
\hline A modell kifejtése & $\begin{array}{l}\text { - Siker vagy bukás } \\
\text { történetéból kirajzolódó } \\
\text { kvalitatív mintázat }\end{array}$ & $\begin{array}{l}\text { - Kulcstényezók, mutatók } \\
\text { összefüggésének iránya, } \\
\text { nagyságrendje }\end{array}$ & $\begin{array}{l}\text { - A tényezók egymásra } \\
\text { hatásának formalizált } \\
\text { modellje }\end{array}$ \\
\hline Tipikus felhasználás & - Javaslattétel, tanácsadás & - Megértés és általánosítás & $\begin{array}{l}\text { Érzékenységvizsgálat, } \\
\text { forgatókönyv-elemzés }\end{array}$ \\
\hline Módszertani eszköz példák & $\begin{array}{l}\text { - Esettanulmány } \\
\text { benchmarking, szerepjátékok }\end{array}$ & $\begin{array}{l}\text { - Gondolati térképek, } \\
\text { stratégiai térképek }\end{array}$ & $\begin{array}{l}\text { - Táblázatkezelók, üzleti } \\
\text { játékok }\end{array}$ \\
\hline
\end{tabular}

ban komplex üzleti helyzetben hoznak döntéseket, ahol az egyidejú információbóség és -hiány megnehezíti a háttérben lévő összefüggések felrajzolását. Néhány vállalat ezt felismerve készíttet önmagáról esettanulmányt, ennek összeállítása, majd megvitatása során ötleteket szerezve az üzleti modellje továbbgondolásához. Más vállalatok új kezdeményezéseik tervezésekor iparágon belüli vagy akár kívüli példaképek, elődök esettanulmányait dolgozzák fel, lehetôségeket, legjobb gyakorlatokat és buktatókat kutatva (esettanulmánybenchmarking). A (fóleg informatikai) beruházások tervezésének újszerú módszertana, az üzleti esettanulmány ugyanakkor csak nevében kapcsolódik ide. Bár az üzleti modellezéshez hasonlóan az elbeszélés és a számok világának összekapcsolásával dolgozik, nem modellezés.

II. fokozat: a térkép. Szervezeti és folyamatábrák szerkesztésére számos módszertani ajánlás és célszoftver létezik. Nem így a múködés mögötti logika grafikus felvázolására. Léteznek gondolati térkép készítését támogató, ún. mindmapping alkalmazások, ezeket azonban inkább bizonyos feladatok rendszerezésére, ellenôrző listák látványos bemutatására, esetleg megbeszélés-emlékeztetôk készítésére használhatjuk (Drótos - Kupás, 2004). Kifejezetten az üzleti modellek leírására és ábrázolására két vezető módszertan van kialakulóban (Gordijn et. al., 2005). Gordijn - Akkermans (2001) $e^{3}$ value módszertana a végsô fogyasztói érték előállítására és az ellátási láncon való áramlására összpontosít, többek között a szoftvertervezésben használt UML egységes modellezési nyelvre építve. Osterwalder (2004) BMO (üzleti modell ontológia) módszertanában hagyományos stratégiai kategóriák (erőforrások és képességek, értékesítési csatornák stb.) mentén készuil térkép, az internetes tartalmakhoz kifejlesztett XML (kiterjeszthető leíró nyelv) felhasználásával. A gyakor- latban azonban nagyon is sokféle ábrázolásmódot találhatunk alkalmasnak, amelyek mindig az adott esetben lényeges szemszögbool készülnek. Makó és szerzótársai (2003) digitális értékláncokról készítettek térképeket különbözô megvilágításból. Megemlítendő, hogy az üzleti modell ábrázolásánál a gyakorlatban valamivel elterjedtebb rokon módszertan a stratégiai térkép készítése, amely a vállalati stratégia lebontását, megvalósításának nyomon követését támogatja. Kaplan és Norton (2000) ajánlása szerint a balanced scorecard kiegyensúlyozott mutatószámai közötti összefüggések ábrázolása ,hozzásegíti a szervezeteket, hogy a stratégiájukat egy összetartozó, egységes és szisztematikus keretben tekinthessék át".

III. fokozat: a szimulátor. A vállalati vezetői képzésekben gyakran szerepel valamilyen üzleti játék modul, ahol a résztvevốk csoportjai egy szimulált piacon versenyezhetnek egymással. Egyes szoftverek egy-egy vállalati területre (például disztribúciós hálózat vagy marketingstratégia) összpontosítanak, míg mások egy vállalat egészének a múködését modellezik. Megfelelő paraméterezéssel akár a valós üzleti problémához hasonló helyzettel is kísérletezhetnek a résztvevoók, jóllehet, az igazi kísérletezés pont a paraméterezésben van, mert a paraméterezés jelenti a piacra, versenytársak viselkedésére, fogyasztói magatartásra való feltevések becslését, azaz az üzleti modellezés fô kihívását. A grafikus üzleti modellek felól közelítve adódik a lehetôség, hogy amennyiben ismerjük az üzletünk fő összefüggéseinek irányát, nagyságrendjét, az összefüggések pontosabb becslésével akár számszaki modellhez is juthatunk. Bizonyos szintig az általános táblázatkezelő programok is segítségül hívhatók az olyan elemzésekhez, amikor az üzleti modell egyes tényezőit változtatva azok hatását vizsgálnánk. Egyes vállalatok ezt felismerve egyedi fejlesztésú programok nélkül is 
képesek összetettebb szimulációk végzésére (egy korai példa Hall - Menzies, 1983). Emellett a fent említett $\mathrm{e}^{3}$ value módszertan az értékteremtés számszaki követésében is segít.

\section{Az üzleti modellek jellemzó összetevôi}

A modellezés általános jelentéséból fakadóan elvárás az üzleti modellekkel szemben, hogy a célok szempontjából fontos elemeket magába foglalja. Ahogyan a stratégiai térképezéskor segítségül hívhatók a balanced scorecard nézópontok, úgy az üzleti modellezés során is hasznos lehet az üzleti modellek fó összetevőit azonosítanunk. Magretta (2002) például négy kérdés megválaszolását várja az üzleti modellektól: ki a fogyasztó, mi az érték számára, honnan érkezik a bevétel, mitôl lesz mindez gazdaságos? További kutatók eltérő nézôpontból építik fel az üzleti modellek elvi vázát.

- Venkatraman (2000) mintha egy szervezetet próbálna leírni, amikor az üzleti modellt a stratégiai jövôkép, az eróforrás-hozzárendelés, a vállalatkormányzás, és a múködés infrastruktúrája eredőjeként tekinti.

- Amit- Zott (2001) az üzleti modell középpontjában álló (értékteremtô) tranzakció kifejtését tartja fontosnak, méghozzá a tranzakció tartalma, struktúrája és kormányzása köré csoportosítva.

- Különböző értéktényezốk szereplő́k közötti áram- irányú kapcsolódási pont segítségével közvetítik az értékátadásokat a szervezet vagy tevékenység „,belseje" felé.

- O’Daniel (2001) szerint négy szempontból (szóhasználatában szerepból) kívánatos jellemezni az üzleti modelleket: ezek a szervezódés (a piactól a hierarchiáig), a strukturális elemek (a szerveződés infrastruktúrája), a funkciók (a strukturális elemek betöltése során), és a kereskedelmi szerepek (árazás, termék fókusz, megvalósítás).

Az üzleti modellezésról szóló kiadványok nagyobb része azonban tartalomjegyzékszerúen kísérli meg felsorolni az üzleti modellek összetevôit. Ezekból négy (mondhatjuk: három plusz egy) markáns tétel emelkedik ki, elsôsorban Alt - Zimmermann (2001) javaslatainak összevonásával (2. táblázat):

- értékajánlat,

- szervezeti/hálózati modell (struktúrák és folyamatok),

- bevétel-költség modell,

- infrastrukturális és szabályozási környezet (mint „keresztbe fekvớ" összetevô).

Bármely fenti fokozat mentén fejtjük ki az üzleti modellt, e négy összetevốt érdemes végiggondolnunk. Ez az egységes keret segíthet különböző üzleti modellek és ellátási láncok összevetésében: ezzel kapcsolatban kiemelhető Makó és szerzőtársai (2003) tanulmánya, melyben az új gazdaság digitális értékláncait hat európai régióban elemezték e négy összetevő mentén.

2. táblázat

Az üzleti modellek tipikus összetevői

\begin{tabular}{|c|c|c|c|c|}
\hline $\begin{array}{l}\text { Pateli } \\
(2002)\end{array}$ & $\begin{array}{l}\text { Tapscott } \\
\text { (1999) }\end{array}$ & $\begin{array}{l}\text { Alt és Zimmermann } \\
\text { (2001) }\end{array}$ & $\begin{array}{l}\text { Osterwalder és } \\
\text { Pigneur (2002) }\end{array}$ & $\begin{array}{c}\text { Mahadevan } \\
(2000)\end{array}$ \\
\hline - Küldetés és stratégiai célok & - Fó motívum & \multirow{4}{*}{ - Küldetés } & \multirow{4}{*}{ - Termékinnováció } & \multirow{4}{*}{ - Értékajánlat } \\
\hline - Értékteremtés & & & & \\
\hline - Múködési kör & - Ertekajantal & & & \\
\hline - Alapvető képességek & \multirow{2}{*}{ - Tudás szerepe } & & & \\
\hline — Értéklánc, -hálózat & & - Struktúra & \multirow{2}{*}{$\begin{array}{l}\text { Infrastruktúrra } \\
\text { menedzsment }\end{array}$} & \multirow{4}{*}{ - Logisztikai áramlat } \\
\hline $\begin{array}{l}\text { - Tevékenységek } \\
\text { és folyamatok }\end{array}$ & - Kulcsfolyamatok & \multirow{3}{*}{ - Folyamatok } & & \\
\hline & \multirow[b]{3}{*}{ - Vevők szerepe } & & \multirow{2}{*}{ - Vevői kapcsolatok } & \\
\hline - Piaci trendek & & & & \\
\hline $\begin{array}{l}\text { - Árazási politika és bevételi } \\
\text { áramlatok }\end{array}$ & & - Bevétel & - Pénzügyek & - Bevételáramlat \\
\hline - Szabályozás & - Bizalom & - Jogi kérdések & & \\
\hline - Technológia & & - Technológia & & \\
\hline
\end{tabular}

lását emeli ki Gordijn és Akkermans (2001). Külön hangsúlyozzák, hogy a szereplók érintkezési felületekkel rendelkeznek, melyek egy-egy ellentétes
(A táblázat fejlécében szereplő hivatkozások saját összehasonlítása; a táblázat balról jobbra a részletezóbb felsorolásoktól az átfogóbbak felé halad.) 


\section{Az üzleti modellezés gyakori buktatói}

Más menedzsmentgyakorlatokhoz hasonlóan az üzleti modellezés sem csodaszer. A gyógyszerekkel viszont annyiban mutat hasonlatosságot, hogy a helytelen használat vagy „félrekezelés” - a várt javulások elmaradásán túl - katasztrofális következményekkel járhat. Valójában, az internetes vállalkozásokkal kapcsolatosan az üzleti modellezés olyan szintú és számú téves gyakorlatáról olvashattunk, hogy magának a menedzsmentgyakorlatnak a hasznossága is megkérdôjeleződött. A tévesen kigondolt vagy felhasznált üzleti modellek nem az új gazdaság sajátosságai. A menedzsment - és fóleg a marketing - szakirodalom bőven mutat internet elốtti példákat az üzleti modellben való gondolkodás félresiklására (Magretta, 2002). Az alábbiakban három tipikus buktatóra térek ki.

Az első buktató az üzleti modell változatlan formában való alkalmazása függetlenül attól, hogy milyen körülmények közepette vetik be. Magretta (2002) a Disneyland klasszikus példáját mutatja be. Az Amerikában sikeres modellt változatlanul kezdték alkalmazni Franciaországban, de az európai piac számos tekintetben másnak bizonyult. A modellben változtatni kellett többek között az éttermek múködtetése, az éttermi bevételek szerepe, a legnépszerúbb játékok és az átlagos játékok igénybevételének folyamata terén. A sikeresnek kikiáltott üzleti modellek másolása tehát nemcsak a másolás tökéletlenségén, hanem a másolás értelmességén (a körülmények különbözőségén) is megbukhat.

Az üzleti modellek könnyen túnnek kész útmutatásnak. Porter (2001) Stratégia és internet címú cikkének intelme, hogy az az internetes üzleti modell, amelyhez nem kapcsolódik megkülönböztetô stratégia, hosszabb távon biztosan kudarchoz vezet. Ez a második buktatója lehet valamennyi üzleti modellnek. Tapscott (2001) megjegyzi, hogy elterjedt egy olyan (elhibázott) hozzáállás, hogy minden olyan üzleti modell hasznot hoz, amelyik az internetre épül. Az internet helyére bármilyen csodatechnológia vagy formula beilleszthetô, az nem menti fel az üzleti modellt a versenystratégia szabályai alól.

Az üzleti modellezés fó erénye, hogy a kulcstényezók közötti összefüggéseket világítja meg. A harmadik buktató ezért az, ha egyoldalúan, csupán néhány tényezốre - például csak az értékteremtésre, a bevételszerzésre, vagy a szervezetközi kapcsolatokra - koncentrálva fogalmazódik meg a modell. Számos briliáns üzleti ötlet szerepel népszerú menedzsmentkönyvekben, melyeknél azonban egy-egy „apróság” - például bevételi forrás, vevő, vagy beszállító - hiányzott ahhoz, hogy életképes legyen.

\section{Internetes üzleti modellek szerkesztése}

A cikk elsó részében bemutattam az üzleti modellezés fogalmát, alkalmazási területeit és tipikus buktatóit. A megállapításokból következik, hogy egy új üzleti ötlet kidolgozásánál hasznos segédeszköz lehet az üzleti modell felvázolása, függetlenül attól, hogy „hagyományos” vagy internetes kezdeményezésról beszélünk. Egy internetes vállalkozás esetében azonban erôs a csábítás, hogy valamely közismert internetes üzleti modellt vegyük alapul. Ebben a fejezetben a legkülönbözóbb szakirodalmi modelleket bontom olyan javaslatokra, amelyból a közismerteknél átgondoltabb, egyedibb modellek barkácsolhatók (ami továbbra sem helyettesíti a stratégiát).

3. táblázat

\section{Az internetes üzleti modellek fókuszai}

\begin{tabular}{|l|l|}
\hline Megkülönböztetó szempont & Internetes üzleti modellek \\
\hline A szervezet viszonya az internethez & Tisztán internetes, click-and-mortar \\
\hline A piac irányultsága & $B 2 B, B 2 C$ \\
\hline Ágazat & Gyártó, nagykereskedó, kiskereskedó \\
\hline Résztvevő felek koncentrációja & Egy vevó egy eladó, 1-sok, sok-1, sokszereplös \\
\hline Funkció az ellátási láncban & Közvetett, ezen belül piactér és portál, közvetlen, ezen belül e-bolt és közvetlen eladás \\
\hline Közvetítési mechanizmus & Tözsde, árverés, aggregálás/katalógus \\
\hline Struktúra & Agora, szövetség, tudáshálózatok, e-szervezet \\
\hline Bevételi modell & Ingyenes, fizetett, ezen belül elóre vagy utólag \\
\hline Tevékenység & Ár-összehasonlítás, termékkapcsolás, internetes közmú \\
\hline Összehangoltság, fejlettség & Tartalom, interakció, tranzakció, transzformáció \\
\hline
\end{tabular}

(Alt - Zimmermann, 2001; Chen, 2003; Essler - Whitaker, 2001; Kühn - Junginger - Bayer, 2000; valamint Osterwalder - Pigneur, 2002 felhasználásával) 
Az internetes üzleti modellekre minden szerzőnek van egy saját listája. Ez akár a modellek lépésenkénti átgondoltságára és kidolgozásuk mélységére is utalhatna. Valójában sokkal inkább azt látjuk, hogy a modellek átfednek, vagy ugyanazon modellek köszönnek vissza különbözô néven - rendszerint olyan néven, amely valamelyest misztikussá teszi az adott modellt -, vagy éppen összeegyeztethetetlenek eltérő megközelítésük miatt.

Az internetes üzleti modellek sokféleségének egyik oka, hogy az elvonatkoztatás eltérô szintjén készültek. A téma legtöbb publikációja az ellátási láncban betöltött funkciókra építi modelljeit. Ezek közé azonban gyakran keverednek közvetítési mechanizmusok, bevételi források, vagy konkrét tevékenységek, mint az adott modell lényegi elemei, meghatározói. A 3. táblázatban bemutatott megkülönböztetô szempontok mentén a szakirodalom internetes üzleti modelljei elviekben egy tízdimenziós térben rendszerezhetốk. Három szempont összekapcsolásával azonban áttekintést kaphatunk a leggyakrabban említett típusokról, ahogyan ezt a 3. ábra mutatja. (Részletesen elemzi ezeket Móricz, 2005.) nek. Egyes területek, mint például a tartalom-intenzív iparágak, folyamatos változásban maradnak: például a hagyományos újságírást fenyegetô on-line portálok immár az olvasók által létrejövő tartalom üzleti modelljeivel, a blogszférával versenyezhetnek. Más iparágakban, mint például a légiközlekedésben, egy nagyobb hullámban változtak az uralkodó üzleti modellek: a „fapados modell” ötletétól vezérelve (vagy nyomására) számos légitársaság módosított modelljén az internet lehetôségeit kiaknázva, ám az iparág öszszességében a hagyományos mederben halad (lásd McGahan, 2004). Vannak iparágak, mint például a biztosítások, ahol az internet hozta új üzleti modellek egyelőre csak kiegészítik a hagyományos iparági sémát: az internetes biztosítók és az internetes alkuszok megjelenésével a hagyományos biztosítók is elgondolkoznak az új modellek felhasználásáról. Nehéz olyan iparágat említeni, amelyet egyáltalán nem érintettek az internetes üzleti modellek, bár az érintettség meglehetősen alacsony szintư lehet, különösen, ha olyan környezeti tényezóket is figyelembe veszünk, mint a gazdaság fejlettsége, a piac (internetre) érettsége, vagy az ország kulturális hozzáállása.

3. ábra

A tipikus internetes üzleti modellek rendszerezése

\begin{tabular}{|c|c|c|c|c|}
\hline \multicolumn{5}{|c|}{ Internetes üzleti modellek } \\
\hline \multicolumn{5}{|c|}{ Ellátási láncban betöltött szerep } \\
\hline \multicolumn{2}{|c|}{ Közvetítés } & \multicolumn{2}{|c|}{ Integrálás } & \multirow{3}{*}{ Infrastruktúra } \\
\hline \multicolumn{2}{|c|}{ Közvetítés fókusza } & \multicolumn{2}{|c|}{ Integrálás tárgya } & \\
\hline Tranzakció & Közösség és tartalom & Értékesítés és elosztás & $\begin{array}{c}\text { Ellátási lánc és } \\
\text { „termelés” }\end{array}$ & \\
\hline $\boldsymbol{\nabla}$ & $\boldsymbol{\nabla}$ & $\nabla$ & $\nabla$ & $\nabla$ \\
\hline Internetes piactér & Internetes portál & $\begin{array}{c}\text { Internetes } \\
\text { kereskedelem }\end{array}$ & $\begin{array}{c}\text { Internetes ellátási lánc } \\
\text { integrálás }\end{array}$ & Internetes közmú \\
\hline $\begin{array}{l}\text { - Katalógus } \\
\text { - On-line árverés } \\
\text { - Tőzsde } \\
\text { - Vállalatközi } \\
\text { - Internetes áruház } \\
\text { - Csoportos } \\
\text { vásárlás } \\
\text { - Te mondd az árat } \\
\text { - Fogyasztóközi } \\
\text { - Közbeszerzési }\end{array}$ & $\begin{array}{l}\text { - Tartalomszolgáltató } \\
\text { - Ár-összehasonlító } \\
\text { - Virtuális közösség } \\
\text { - Információközvetítô } \\
\text { - Közösségépító honlap }\end{array}$ & $\begin{array}{l}\text { - B2B } \\
\text { - E-bolt } \\
\text { - Közvetlenül } \\
\text { a gyártótól } \\
\text { - On-line szolgáltatások } \\
\text { - On.l. marketing } \\
\text { - Társulás }\end{array}$ & $\begin{array}{l}\text { E-beszerzés } \\
\text { - Értékláncintegráció } \\
\text { - Együttmúködési } \\
\text { platform }\end{array}$ & $\begin{array}{l}\text { - Értéklánc- } \\
\text { katalizátorok } \\
\text { - Internet-infrastruk- } \\
\text { túra } \\
\text { - Alkalmazás- } \\
\text { szolgáltatás }\end{array}$ \\
\hline
\end{tabular}

Az internetes üzleti modellek hangsúlyossá válása csak látszólag korlátozódik néhány speciális iparágra. Ahogy az új gazdaság és a hagyományos összeolvad, a hagyományos vállalatok és iparágak is új lehetôségekkel, de egyúttal fenyegetésekkel is szembesül-
Bár csupán a kérdés jelentôs elnagyolásával vállalkozhatunk a hagyományos és az internetes üzleti modellezés összehasonlítására - minthogy ilyen szélsőségesen hagyományos vállalat, iparág, vagy üzleti modell alig létezik -, 4. táblázat kiemel néhány különbséget. 
A következókben a táblázat jobb oldalát részletesebben is bemutatom, majd külön fejezetben tárgyalom az internetes üzleti modellezés vitapontjait, melyek éppen arra hívják fel a figyelmet, amiben a hagyományos és az internetes üzleti modellezés hasonló, összefonódó.

\section{A szervezeti/hálózati modell összetevó}

Miközben az új gazdaság tézisei között kiemelten szerepel az értékláncok szétbomlása és az ellátási láncok átalakulása, az internetes üzleti modellek többnyire egyedi szervezetben gondolkodnak (ezt is mutatja a

Az internetes üzleti modellezés összevetése az elméleti „hagyományos” modellezéssel

\begin{tabular}{|l|l|l|}
\hline & \multicolumn{1}{|c|}{$\begin{array}{c}\text { „Hagyományos” } \\
\text { üzleti modellezés }\end{array}$} & $\begin{array}{c}\text { Internetes } \\
\text { üzleti modellezés }\end{array}$ \\
\hline Értékajánlat & $\begin{array}{l}\text { A piaci igények magas értéket képviseló } \\
\text { módon való kielégítése }\end{array}$ & $\begin{array}{l}\text { „Kifordított” értékajánlatok, } \\
\text { új értékteremtési lehetőségek keresése }\end{array}$ \\
\hline Szervezeti/hálózati modell & Vertikálisan integrált vállalat értéklánca & $\begin{array}{l}\text { Dinamikus értékhálózatok, specializálódó } \\
\text { szerepek }\end{array}$ \\
\hline Bevétel-költség modell & Rögzített érték-ellenérték kapcsolatok & $\begin{array}{l}\text { Rugalmasan vegyíthető hozzájárulások } \\
\text { és bevételi áramok }\end{array}$ \\
\hline Infrastruktúra és környezet & $\begin{array}{l}\text { Irányítást } \\
\text { és ellenórzést támogató IT, } \\
\text { viszonylag állandó szabályozási környezet, } \\
\text { kialakult társadalmi kapcsolatok }\end{array}$ & $\begin{array}{l}\text { Múködéskritikus IT, } \\
\text { megkésett jogalkotás, } \\
\text { kérdések a bizalom és a használati } \\
\text { szokások területén }\end{array}$ \\
\hline
\end{tabular}

\section{Az értékajánlat összetevó}

A szakirodalom legtöbb internetes üzleti modell leírása az értékajánlattal foglalkozik. A szakcikkek arról szólnak, mi a „lényege” (küldetése) a modellnek, és hogyan (kinek) teremt értéket. Ezek a leírások gyakran mégsem egyértelmúek. Például a közismert internetes piactér modellt előnyök listájával szokták jellemezni, melyek azonban mégsem rajzolnak ki egy összefüggó értékáramlatot. Más modellek esetében egyáltalán nem világos, hogy ki és milyen értéket teremt. Erre példa a Lam - Harrison-Walker (2003) által idézet ,jutalombróker" modell, vagy egy másik, az egyszerúen csak ,ingyenesnek” nevezett. Mahadevan (2000), aki részletesebben vizsgálta az értékajánlat összefüggéseit a legnépszerúbb internetes üzleti modelleken belül, az értékteremtés négy csoportját mutatta be:

- virtuális közösség létrehozása, melyen belül az érték és a tudás egyedi és másolhatatlan módon áramlik,

- az üzletkötés költségeinek drámai csökkenése,

- az információs aszimmetria jövedelmező kiaknázása, azaz valamely érdekelt bizonytalanságának csökkentése, információval való ellátottságának javítása,

- értéknövelt piacteremtô-párosító folyamat.

Mahadevan (2000) úgy vélte, hogy míg az internetes portálok a közösségépítésben és a piacteremtésben, a termék és -szolgáltatás nyújtók pedig a közösségépítésben és az üzletkötés költségeinek csökkentésében jeleskednek, addig a piactereknél (elvileg) mind a négy értékáramlat elófordul.
3. ábra). Az értékteremtésre összpontosítás mellett a modell illeszkedése egy nagyobb láncolatba vagy hálózatba rejtve marad. Az üzleti modellek egy másik része meg azért nem tekinthetó modellnek, mert szinte kizárólag a struktúrák és folyamatok kérdésével foglalkozik, s az értékajánlat kifejtésével alig. Ezek a modellek ugyanakkor támpontul szolgálhatnak ahhoz, hogy hogyan képzeljük el a többi modell (például egy e-bolt vagy egy információközvetító) szervezeti/hálózati felépítését.

A szervezeti/hálózati modell alapváltozatának, a klasszikus értékláncnak továbbfejlesztésekor Rayport és Sviokla (1995) hangsúlyozza: az ún. értékmátrixban kiosztandó az információgyújtés, -rendezés, -válogatás, -összefoglalás és -elosztás szerepe.

A Werbach (2000: 88. o.) szerint az értékteremtés az értékhálózatokban alkotó, összekapcsoló (ez a cikkének címében is szereplő szindikátor), elosztó és fogyasztói szerepeken keresztül zajlik. Minden üzleti modellnél - különösen a tartalomintenzív iparágakban - érdemes volna végiggondolni, hogy egy adott üzleti modell miként kapcsolódik e szerepek hálózatába.

Tapscott - Ticoll Lowy (1998) az ún. „e-business közösségekben" megfigyelt hálózatokat írják le, melyeket b-webnek kereszteltek el (4. ábra). Rámutatnak, hogy az érték előállítása történhet hierarchikusan, de önszervezôdố módon is (lásd még Drótos - Nemeslaki, 2002; Móricz - Drótos, 2006), mégpedig a központi irányítás különbözố szintje mellett. Az 
on-line újságok például leggyakrabban az „off- line világból" származó értéklánc modellnél maradtak. Az olvasók szúkebb köre által írt webnaplók becsatornázásával az aggregálás irányába mozdulhatnak. Vannak azonban ún. blogkeresôk, melyek az olvasóik szavazatai alapján automatikusan válogatnak címoldalra ilyen webnapló bejegyzéseket, ami a görög piactér hasonlatával írható le. A legismertebb internetes lexikon, a Wikipedia azonban elkötelezett a szócikkek folyamatos egységesítése és „tisztítása” mellett, ezért minimális hierarchia mellett szoros ellenôrzést biztosít az önszerveződő szerzók felett. (Megjegyzendô, hogy Tapscott és társai jóval konkrétabban fogalmazták meg az öt szerveződési/hálózati modellt, amelyek így erôsen köthetốk a 3. ábra öt fó internetes modelljéhez.

\section{Tapscott értékhálózati architektúrái (üzleti modelljei)}

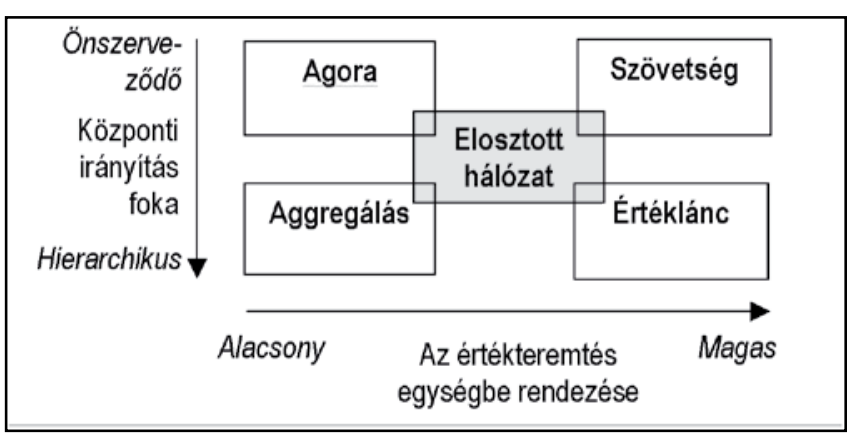

(Tapscott - Ticoll - Lowy, 1999: 206. o. kis módosítással)

Tapscott szerzőtársaival (2000) az öt hálózati típusban megfigyelhetô szerepekre is kitér, az értékteremtés résztvevőit öt „osztályba” sorolják:

- a vevớk, akik nemcsak befogadják a feléjük nyújtott értéket, de hozzá is járulnak,

- a környezetet szolgáltatók, akik az értékteremtést megtervező, szabályozó különböző tevékenységeket vezetik,

- a tartalomszolgáltatók, akik a vevôi igényeket kielégítő termék vagy szolgáltatás magját adják,

- a kereskedelmi szolgáltatók, akik az üzletkötéseket bonyolítják a vevő́kkel, valamint

- az infrastruktúra-szolgáltatók, akik az elóbbiek informatikai és fizikai hátterét (szerverek, jármúvek, ingatlanok stb.) biztosítják.

Rayport, Werbach, valamint Tapscott et. al. koncepciója egyaránt rámutat arra, hogy az internetes üzleti modellek értékteremtése legalább annyira múlik a résztvevők közötti szerepelosztáson és folyamaton, mint a szúken vett értékajánlaton.
Mahadevan (2000) elgondolása szerint a legelterjedtebb internetes üzleti modellek nagyon is eltérő szervezeti/hálózati modellre építenek. Míg a közvetlenül a gyártó modellnek nevében a lényege, a közvetítốk kiiktatása, addig a portálok esetében közvetítô lép be, a piacterek esetében pedig többletszolgáltatásokat nyújtó közvetítéssel találkozunk. A szervezeti/hálózati modell részletes elemzéséhez Amit és Zott (2001: 514. o.) a stratégiai hálózatok elméletének elemzési keretét javasolják.

\section{A bevétel-költség modell összetevö}

Az internetes üzleti modellekról szóló cikkeket olvasva olybá túnhet, hogy a modell fő motívuma (például piactér, vagy e-bolt) egyúttal a bevételi áramlatokat is egyértelmúvé teszi. Valójában pont azért van értelme modellezésról beszélnünk, mert a bevételek különböző forrásból származhatnak, és ezek nagysága, tartóssága többek között az értékajánlattal és a szervezeti/hálózati modellel kapcsolatos választásokon múlik. Applegate és Collura (2000) összegyújtötték az internetes modellek esetében leggyakoribb bevételi forrásokat vagy áramlatokat. Az 5. táblázat jelzi, hogy a legtöbb internetes üzleti modell esetében ebból a széles „kínálatból” választhatjuk meg, hogy melyik bevételi forrásokban gondolkozunk.

5. táblázat

Internetes üzleti modellek jellemző bevételi forrásai

\begin{tabular}{|l|l|}
\hline Kereskedelem & Közösség \\
- Termékértékesítés & — Reklám- és hirdetési díj \\
- Szolgáltatásnyújtás & - Társulási, partneri díj \\
- Jutalék, tranzakciós díj & - Tagsági díj \\
\hline Tartalom & Infrastruktúra \\
- Előfizetési díj & - Hardver-, szoftvereladás \\
- Letöltési díj & - Installáció és integráció \\
- Regisztrációs, részvételi díj & - Karbantartás, fejlesztés \\
& - Kapacitásbérlés díja \\
& - Hozzáférés díja \\
\hline
\end{tabular}

(Applegate - Collura, 2000: 15. o.)

A már többször idézett Mahadevan (2000) a bevételekkel kapcsolatban is összevontabb kategóriákat említ. A közvetlenül a gyártótól modellben a hagyományos tevékenységek feletti nagyobb haszonkulcs és az árazási stratégiák a bevételi áramlatok fó összetevôii. Az internetes portálok és a piacterek elsősorban a közvetítés alapján, valamint hirdetésekből szereznek bevételeket, ez a piacterek esetében az információs aszimmetria ki- 
aknázásának ellentételezésével egészül ki. Mindhárom modellben szerepet kaphat az önkéntes hozzájárulások sajátos „bevételi” formája.

Még azok az internetes üzleti modellek is, amelyek hangsúlyt fektetnek a bevételi áramokra, gyakran megfeledkeznek a kapcsolódó költségek számbavételéról. Sôt, egyes cikkek külön ki is emelik, hogy az internetes üzleti modellek ,olcsóbbak”, mint a hagyományos üzlet, mert „,nem kell más hozzá, mint egy számítógép, meg minimális személyzet".

Valójában éppen fordítva van, a költségkategóriák eltérése a „megszokottól” a költségek gondosabb áttekintését, tervezését, kontrollját kívánja meg. A témával foglalkozó kevés publikáció között Applegate és Collura (2000: 16. o.) a következő költségkategóriákat emeli ki:

- emberek és partnerkapcsolatok (szükséges képességek és tapasztalatok megszerzése),

- hirdetés, marketing és értékesítés (az offline és az online médiában is),

- üzletfejlesztés (vállalkozás, közös vállalat megtervezése és felállítása),

- anyagok és készletek (a termék előállításához felhasznált javak, a termék-kiegészítóket is ide értve),

- beruházások az infrastruktúra nélkül (speciális berendezések, tókeköltség),

- kutatás-fejlesztés (digitális termékek és szolgáltatások tervezése és megvalósítása),

- fizikai létesítmények és infrastruktúra (központ, irodák, gyárak, raktárak, elosztóközpontok, üzletek, szolgáltatóközpontok),

- információtechnológiai infrastruktúra (számítógépek és perifériáik, adatbázisok felállítása és múködtetése, szoftvertervezés, -fejlesztés, -bevezetés, -karbantartás, hálózat és hálózati berendezések kiépítése és múködtetése).

A bevétel-költség modell fontosságát mutatja a mozifilmkölcsönzéssel kapcsolatos újítások történelme. A Blockbuster az 1980-as években azzal hívta fel magára a figyelmet, hogy nem vásárolta meg - a korábbi gyakorlat szerint - tetemes összegért a filmek korlátlan alkalommal való kölcsönadási jogát, hanem a kölcsönzési díj egy részének átadásáról állapodott meg a stúdiókkal, így csak a tényleges kölcsönzéskor merült fel költség. Egy évtizeddel késóbb a Netflix több ponton is újszerú modellt vezetett be a DVD kölcsönzésben: rögzített havidíjat szedett, és csupán az egyszerre a fogyasztónál lévő filmek számát korlátozta, a kölcsönzési idốt nem. A házhozszállításon alapuló rendszer merôben új költségstruktúrát eredményezett, miközben a fogyasztók lényegesen kényelmesebben kölcsönözhettek (Morris, 2003).

\section{Az infrastrukturális és szabályozási környezet összetevö}

Alt és Zimmermann (2001), valamint Pateli (2002) az előző három kérdéskört átfogó, másodlagos összetevớként említi a technológiát és a szabályozási környezetet.

$\mathrm{Az}$,infrastruktúra-szolgáltatásokat” az üzleti modelleken keresztül ívelő témának tekinti Weill és Vitale (2002) is. Más szerzók a bizalom kérdését tekintik hasonlóképp (amely a szervezeti/hálózati modell része is lehet).

A technológia lehetôség és kényszer az új üzleti modellek tervezésénél és bevetésénél (Alt - Zimmermann, 2001). Az üzleti modell részét kell képezze az, hogy milyen információtechnológiára építkezik az értékteremtés során. Másfelől a biztonság, az adatvédelem kérdései által is különbözô mértékben érintettek az egyes üzleti modellek. Weill és Vitale (2002: 26. o.) táblázatban foglalja össze, hogy nyolc különböző internetes üzleti modell esetében mennyire játszik fontos szerepet kilenc meghatározott „infrastruktúra-szolgáltatás”. Felméréssel támasztják alá, hogy a biztonság valamennyi internetes üzleti modellnél alapvetô kérdés, míg a legtöbb infrastruktúrával kapcsolatos szolgáltatást a portál-tartalomszolgáltató modell igényli. A jogi környezet szintén hatással van az üzleti modellekre, mindenekelőtt az adózás, a hitelesség, a titoktartás és a szerzói jog kérdéseivel. A további támogató, lehetôséget teremtő és korlátozó hatások között számos kulturális elemmel találkozunk.

Anélkül, hogy túlhangsúlyoznák ezen összetevô fontosságát az üzleti modellezésben, kijelenthetjük, hogy az elsố három összetevố alapján végiggondolt modellnek át kell jutnia az infrastrukturális és szabályozási kérdések tesztjén. Azaz, nem lehetetleníti-e el a kigondolt modellt valamilyen infrastrukturális vagy szabályozási tényező? Másrészt, nem derül-e fény például olyan technikai lehetôségre, amely kiaknázatlanul maradt?

A szakirodalomban a modellek leggyakrabban természetesnek veszik, hogy az internet mint infrastruktúra a modell alapja, és mélyebb elemzések ennek nyomán nem készülnek. Ahogy azonban az internet-technológia a mobil eszközöktól a háztartási gépekig terjed, megkerülhetetlenné fog válni ezen összetevő hangsúlyos tárgyalása. Ahogy az internetes üzleti modellek a társadalom újdonságkeresô rétegén túli tömegeket kezdik megszólítani, reflektorfénybe fognak kerülni a - kíváncsiság hajtotta „korai kipróbálók" esetében jóval kevésbé kritikus - kulturális különbségek. 


\section{Az összetevók összekapcsolása}

Az előbbiekben bemutatott négy alapvetô üzleti modell összetevôvel kapcsolatban bemutattam a tipikus témaköröket, kérdéseket. Ezek végiggondolása árnyalja, testre szabja az üzleti modellt. Egy jól kigondolt internetes üzleti modell az értékajánlat, a szervezeti/hálózati modell és a bevétel-költség modell tekintetében a már kidolgozott elméleti opciókat vegyíti. Nem öt, nem is harminc, hanem lényegesen több internetes üzleti modell képzelhetố így el. Továbbá, e modelleket aztán adott környezetben egy stratégiával kell összhangba állítani, ami tovább differenciálja a modellt. Nem igaz tehát, hogy az internetes üzleti modellek szükségszerúen az egyediség rovására mennek. Csupán a modell teljes felépítésére van szükség. $\mathrm{Az}$ internetes üzleti modellek továbbgondolását ez az elemzés abba az irányba tereli, hogy egy adott modell minden lényeges tényezôt vegyen számításba, hozza meg a velük kapcsolatos döntéseket, és elemezze ki a közöttuik lévő összefüggéseket Az összetevốk közötti összefüggés keresésében egy további hasznos támpont lehet Pigneur (2002) üzleti modell sablonja, amely az általam bemutatotthoz hasonló négy fó pillér egymásba ágyazottságát ábrázolja.

\section{Az üzleti modellek összetevôinek általános összefüggésrendszere}

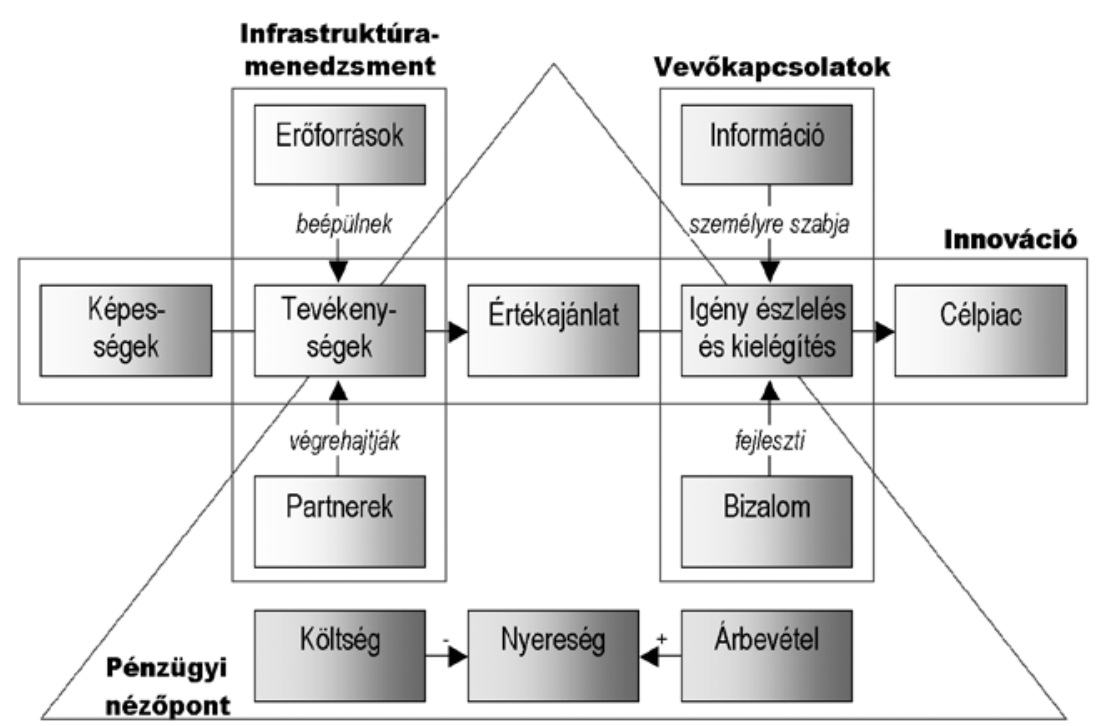

(Pigneur, 2002: 1. o.)

\section{Az internetes üzleti modellezés gyakori buktatói}

Az üzleti modellezéssel kapcsolatban bemutatott gyakori buktatók az internetes kezdeményezések esetében is sưrún felmerültek. Van azonban emellett három előfeltevés, amely kifejezetten az e-business körül ala- kult ki, és amely tévútra vezethet az internetes üzleti modellezés során. Az ingatag előfeltevések a következók:

- az internetes üzleti modellek nem a hagyományos üzletmenet „elektronikus” változatai, hanem radikálisan új lehetôségek,

- az internetes üzlet elszakad a fizikaitól, jellemzővé válik a csak fizikai vagy csak információs üzletben való részvétel, versenyzés,

- az internetes üzleti modellek általánosan és korlátlanul bevethetốk, és az értékajánlat, a folyamatok és a bevételforrások tisztázásával, valamint egy megkülönböztetô stratégia hozzárendelésével lefedik a figyelembe veendố tényezók körét.

Az első előfeltevés jelenik meg a legmarkánsabban. „Az internetre építetten a szervezetnek és külső egyedekkel való párbeszédének alapvetôen új üzleti modelljei jelentek meg”- írja Tapscott (1999: 199.o.)., „Az internettel mint új médiummal együtt az üzlet folytatásának új útjai is érkeztek" - olvashatjuk Timmersnél (1998: 3. o.). A szakirodalomban a leggyakrabban talán éppen ốket hivatkozzák, így megközelítésük valóban az internetes üzleti modellek előfeltevésévé vált. Az Electronic Markets folyóirat üzleti modelleknek szentelt különszámában Essler és Whitaker (2001: 12.

5. ábra o.) majdnem egy oldalt szán hasonló érvelésének. „Általában az [internetes üzleti modellekról szóló] elemzések újra és újra a való világ fizikai tranzakcióival kapcsolatos történelmi tapasztalatokra építkeznek. (...) Az ezekből a tapasztalatokból származtatott üzleti modellek a kibertér új színpada által csupán támogatott, nem pedig létrehozott folyamatokat ragadják meg. (...) Ezek a modellek alkalmatlanok a kibertér röghöz kötöttségtól megszabadult jellegének leképezésére." Timmers (1998: 7. o.) népszerú internetes üzleti modell csoportosításának egyik szempontja, hogy mennyiben jelent radikális újítást az adott modell a hagyományosakhoz képest. A 3. ábra öt fó modellje közül az internetes kereskedelmet tekinti inkább egy korábbi üzleti modell kiterjesztésének, míg a másik négy modell - leginkább az ellátási lánc integráció - az újító szegmensbe esik koordinátarendszerében.

Az üzleti modellezés elmélete - például, hogy minden üzleti modell a korábbiakat variálja -, valamint internetes tapasztalataink ugyanakkor óvatosságra intenek ezzel az előfeltevéssel kapcsolatban. Az internetes üzleti modellek egyes összetevő́k mentén 
különbözô mértékben tekinthetốk radikálisnak a hagyományos elgondolásokhoz képest. Így a modellben hagyományos és újító elemek keverednek. Egyetlen újítás sem jelenti azonban azt, hogy a modellel bármely vállalat is elszakadhatna a verseny hagyományos erôitốl.

A második előfeltevés konkrétan ritkábban jelenik meg az új gazdaság írásaiban, de annál inkább kirajzolódik „összességében”. A leggyakrabban hivatkozott szerzóket hozhatjuk fel példaként. Evans és Wurster (2000: 15. o., 234. o.) információgazdasági megállapításainak alapja a fizikai és az információs üzlet szétválása, melynek során többek között Negroponte cikkeire is hivatkoznak. A hagyományosan az információt a fizikai folyamatokkal összekötő „üzletek” - érvelésükben - veszélybe kerülnek, mert az információ kihasználására új üzleti modellek specializálódnak. Tapscott (1999: 199. o.) szóhasználatában „iparágról iparágra ezek az új üzleti modellek szétzúzzák a vagyonszerzés régi modelljeit”. Az új modellek középpontjában az információ- és kommunikációtechnológia áll, amely „üzleti modellek széles skáláját teszi lehetôvé" (Timmers, 1998: 4. o.). Kevésbé konkrétan, de a hagyományos és az internetes modellek közötti csekély átjárásra utalnak azok a cikkek is, amelyek a hagyományostól az internetes felé való eltolódásról beszélnek (például Alt - Zimmermann, 2001).

Néhány szerzô - például Coltman et. al. (2001), de az ,ellenkezóleg” hivatkozott Evans és Wurster is - konkrét példákat mutat arra, hogy az ,internetes” üzleti modellek ezzel szemben nemcsak hogy összefonódnak hagyományos, fizikai tevékenységekkel, de e tevékenységek döntôvé is válhatnak a modell sikere szempontjából. Ahogyan az internetes üzleti modellek között átjárás, sốt kapcsolódás van (Chen, 2003), úgy feltételezhetô, hogy hagyományos és internetes modellek is keverednek, ha egyáltalán e különbségtételt indokoltnak tekinthetjük.

A harmadik előfeltevés alapvetően rejtett. Az internetes üzleti modellek ,tálalása”, sốt eleve a modell szó arról szól, hogy amit olvasunk, az számba veszi az adott üzletre ható összes lényeges tényezôt és ezek hatását. A modell alkalmazásához adott „testre szabási" útmutató rendszerint a modell alváltozatai közötti választásra, esetenként egy-két kritikus sikertényezôre összpontosít. Ilyen sikertényező lehet a piactereknél a tyúk vagy a tojás dilemma megoldása - a vevók és az eladók is kivárnak a másik oldal belépéséig (Brunn, Jensen - Skovgaard, 2002) -, vagy az internetes kereskedelemben az utolsó kilométer problémája (Lee - Wang, 2001). Ritkább esetben elemzés szól arról, hogy milyen korlátok akadályozhatják egy internetes üzleti modell sikeres múködését, de a szakirodalom ilyenkor vezetési-szervezési, stratégiai és általános iparági (például technológiaintenzitás), egyszóval „racionális” tényezóket sorol (például Saban, 2001).

Szervezetelméletek, valamint a stratégiai hálózatokról szóló elemzések azonban arra figyelmeztetnek, hogy modelljeink olyan - magatartási, hatalmi, kulturális - tényezôktôl is erôsen függhetnek, amelyek nem technikailag, hanem legfeljebb szociológiai szempontokból tekinthetốk racionálisnak. Az ún. „puha tényezôk” szerepét számos internetes kudarc tüzetesebb vizsgálatakor felfedezhetjük (Drótos -Móricz, 2005).

Összességében azt a következtetést vonhatjuk le, hogy az internetes üzleti modellezés egyre kevésbé tekinthetô önálló területnek. Az üzleti modellezés fố vonásai megegyeznek az internet által kevésbé, vagy éppen jobban érintett iparágakban. Azok a jellemzók pedig, amelyeket az elóbbiekben az internetes üzleti modellezés lényegeként mutattam be, valójában valamennyi vállalat, iparág esetében fontos szempontokká válhatnak.

\section{Következtetések}

Az üzleti modellezésre kétségkívül az internetes üzleti modellek virágzása hívta fel a figyelmet. Valójában az üzleti modellezés egy olyan vezetési eszköz, amely a folyamatmenedzsment és a stratégiaalkotás közötti láncszem lehet. Lényege, hogy egy adott probléma, üzletág vagy (érték)hálózat mögötti tényezók összefüggésére, logikájára mutat rá. Attól függóen, hogy a modellt szövegesen, grafikusan, vagy számszerúsítve fejtik ki, különbözô felhasználási területei lehetnek. A leegyszerúsítés, a képi megjelenítés és a szimuláció megfelelô aránya a vezetók problémalátását, döntéshozatalát, döntései kommunikációját segítheti. Ötleteket, információkat bár adhat hozzá, ugyanakkor nem helyettesíti a stratégiaalkotást az üzleti modellezés.

Az internetes üzleti modellezés során a meglévő, ismert modellek átvétele helyett átgondolt modellalkotás javasolható. Ennek során az értékajánlat, a szervezeti/hálózati modell, a bevétel-költség modell, valamint az infrastruktúra és szabályozási környezet összetevők mentén érdemes a lehetôségeket számba venni. Az internetes üzleti modelleknél sem tekinthetünk el a fizikai folyamatok, a stratégia, valamint számos puha tényező szerepétól. Ezzel azonban visszajutottunk magához az üzleti modellezéshez, amelyen belül egyre kevésbé kell különbséget tennünk „hagyományos” és internetes változat között. 


\section{Meghatározások az üzleti modell fogalmára}

Az üzleti modellek ismert és jellegzetes meghatározásait az általánosabbtól az analitikusabb megközelítésekig haladva mutatja az alábbi gyújtés.

\begin{tabular}{|c|c|}
\hline Szerzố & Az üzleti modell \\
\hline Petrovic et. al., 2001 & $\begin{array}{l}\text { „„...a vállalatnak (mint üzleti rendszernek) a tényleges folyamatai mögött húzódó értékteremtési lo- } \\
\text { gikáját írja le.” }\end{array}$ \\
\hline Magretta, 2002:87 & „,...a vállalat múködését elbeszélő történet.” \\
\hline $\begin{array}{l}\text { Venkatraman - Henderson, } \\
\text { 1998, idézi: Stähler, 2002. 5. o. }\end{array}$ & $\begin{array}{l}\text { „...a virtualizálódó szervezet felépítménye három vektor: a vevói interakciók, az eszközök konfigu- } \\
\text { rációja és a tudás felhasználása mentén.” }\end{array}$ \\
\hline Amit - Zott, 2001: 511. o. & $\begin{array}{l}\text { „,...az üzleti lehetôségek kiaknázásával teremthető érték létrehozására tervezett tranzakciók tartal- } \\
\text { mát, struktúráját és kormányzását írja le.” }\end{array}$ \\
\hline Tapscott, 2001: 5. o. & $\begin{array}{l}\text { „,...a szervezet alapvetó architektúrája, a vevoók számára megkülönböztetó érték nyújtása a megha- } \\
\text { tározó (nemcsak szervezeten belüli) erőforrások felvonultatásával.” }\end{array}$ \\
\hline O'Toole, 2002: 2. o. & $\begin{array}{l}\text { „,...a termékek, a szolgáltatások, az imázs és az elosztóhálózat - és a támogató információtechnoló- } \\
\text { gia - egyedi kombinációja, amellyel a vállalat egyedi értéket termel a piacon.” }\end{array}$ \\
\hline Turban et. al., 2002 & $\begin{array}{l}\text { „....az üzletvitel módja, amellyel a szervezet önmagát fenntartó bevételi áramokat termel. A modell a } \\
\text { vállalat az ellátási láncon való pozicionálását fejti ki.” }\end{array}$ \\
\hline $\begin{array}{l}\text { Weill - Vitale, 2001, } \\
\text { idézi Pateli, 2002: } 2 . \text { o. }\end{array}$ & $\begin{array}{l}\text { „....a vállalat fogyasztói, vevői, szövetségesei és szállítói közötti szerepek és kapcsolatok leírása, } \\
\text { mely a fő termék-, információ- és pénzáramlást, illetve a résztvevő́k fő hasznait azonosítja.” }\end{array}$ \\
\hline Timmers, 1998 & $\begin{array}{l}\text { „...leírja a termék, szolgáltatás és információáramlás rendszerét, ide értve a különbözó üzleti aktorokat és } \\
\text { szerepüket is; továbbá rögzíti a különböző szereplők potenciális hasznait, illetve a bevételek forrásait." }\end{array}$ \\
\hline Osterwalder-Pigneur, 2002 & $\begin{array}{l}\text { „...a vállalat által kínált érték megfogalmazása a különbözó vevői szegmensek irányába, valamint a } \\
\text { vállalat és partnerei hálózata felépítésének - mely ezen értéket elóálítja, értékesíti és eljuttatja - leírá- } \\
\text { sa, továbbá az a kapcsolati tơke, mely nyereségtermelő és fenntartható bevételi áramlatokat generál.” }\end{array}$ \\
\hline
\end{tabular}

További üzleti modell összetevốk a szakirodalomban

\section{Amit és Zott (2001)}

Tranzakció tartalma

Struktúrája

Kormányzása

Chesbrough és Rosenbloom (2002)

Versenystratégia

Értékajánlat

CélpiacÉrtékhálózat

Belsô értéklánc

Költségszerkezet és nyereségtermelés

Gordijn és Akkermans (2001)

Szereplők (actors)

Tevékenységek (value activities)

Értéktényezók (value objects)

Kapcsolódási pontok (value ports)

Érintkező felületek (value interface)

Értékátadások (value exchange)

\section{Hamel (2000)}

Alapvető stratégia

Stratégiai erőforrások

Értékhálózat

Vevői „interfész”
Magretta (2002)

Ki a fogyasztó?

Mi az érték számára?

Hogyan lesz pénz?

Miért lesz pénz?

O'Daniel (2001)

Szerveződés (piac vs. hierarchia)

Strukturális elemek (a szervezódés infrastruktúrája)

Funkciók (a strukturális elemek betöltése során)

Kereskedelmi szerepek (árazás, termék fókusz, megvalósítás)

Remenyi és Brown (2002)

Értékteremtés

A profit- és növekedés motorja

Kiszolgálási rendszer

Bevételt generáló rendszer

Venkatraman (2000)

Stratégiai jövókép

Eróforrás-hozzárendelés

Vállalatkormányzás

A múködés infrastruktúrája
Megjegyzés:

A 2. táblázatban összevetett források nélkül. 


\section{Felhasznált irodalom}

Alt, Rainer - Hans-Dieter Zimmermann (2001): 'Preface: Introduction to Special Section - Business Models', Electronic Markets Vol. 11 (1): 3-9.

Amit, Raphael - Christopher Zott (2001): 'Value Creation in E-Business', Strategic management Journal, 22: 493520.

Antal-Mokos Zoltán - Balaton Károly - Drótos György - Tari Ernó (1997): Stratégia és szervezet. Budapest: Közgazdasági és Jogi Könyvkiadó

Applegate, Linda M. - M. Collura (2000): 'Overview of Ebusiness Models', Harvard Business School Discussion Paper, 9-801-172.

Brunn, Peter - Martin Jensen - Jakob Skovgaard (2002): 'eMarketplaces: Crafting A Winning Strategy', European Management Journal Vol. 20 (June): 286-298.

Chen, Stephen (2003): 'The real value of "e-buiness modells", Business Horisons (November-December): 27-33.

Chesbrough, Henry - Richard S. Rosenbloom (2002): 'The role of the business model in capturing value from innovation: evidence from Xerox Corporation's technology spin-off companies', Industrial and Corporate Change Vol. 11 (3): 529-555.

Coltman, Tim - Timothy M. Devinney - Alopi Latukefu - David F. Midgley (2001): 'E-Business: Revolution, Evolution os Hype?', California Management Review Vol. 44 (1): 57-86.

Dobák Miklós (szerk.) (1996): Szervezeti formák és vezetés, Budapest: KJK

Drótos György - Móricz Péter (2005): 'Critical factors of attracting supply chain network members to electronic marketplaces: The case of Sunbooks Ltd. and the Hungarian Book Trade', EMNET Conference Paper, Budapest

Drótos György - Kupás Tibor (2004): Gondolati térképek készítése, mind mapping technikák alkalmazása az üzleti modellezésben; Előadás, szept. 23., Informatikai menedzsment program, Budapesti Vezetôképzó Központ

Essler, Ulf - Randall Whitaker (2001): 'Re-thinking Ecommerce Business Modelling in Terms of Interactivity', Electronic Markets Vol. 11 (1): 10-16.

Evans, Philip and Thomas S. Wurster (2000): Blown to Bits: How the New Economics of Information Transforms Strategy. Boston: Harvard Business School Press

Gordijn, Jaap - Alexander Osterwalder - Yves Pigneur (2005): 'Comparing two Business Model Ontologies for Designing e-Business Models and Value Constellations', Proceedings of the 18th BLED conference (e-Integration in Action), D. R. Vogel, P. Walden, J. Gricar, G. Lenart (eds.), university of Maribor, cdrom

Gordijn, Jaap - Hans Akkermans (2003): 'Does e-Business Modeling Really Help?', Proceedings of the 36th Hawaii International Conference On System Sciences, IEEE
Gordijn, Jaap - Hans Akkermans (2001) :'E3-value: Design and Evaluation of e-Business Models', IEEE Intelligent Systems 16(4):11-17.

Hall, Roger I. - William B. Menzies (1983): 'A Corporate System Model of a Sports Club Using Simulation as an Aid to Policy Making in a Crisis', Management Science 29(1): 52-64.

Kaplan, Robert S. - David P. Norton (2000): The StrategyFocused Organization. How Balanced Scorecard Companies Thrive in the New Business Environment, Boston: HBS Press. Magyarul megjelent: Kaplan, Robert S. és David P. Norton (2002) A stratégiaközpontú szervezet. Hogyan lesznek sikeresek a Balanced Scorecard vállalatok az új üzleti környezetben? Budapest: Panem

Kühn, Harald - Stefan Junginger - Franz Bayer (2000): How Business Models Influence the Development of Ebusiness Applications, in: Stanford-Smith, Brian and Paul T. Kidd eds. (2000) E-business - Key Issues, Applications and Technologies, Amsterdam: IOS Press, 1024-1030.

Lam, Long W. - L. Jean Harrisson-Walker (2003): 'Toward an objective-based typology of e-business models', Business Horisons (November-December): 17-26.

Lee, Hau L. - Seungjin Whang (2001): 'Winning the Last Mile of E-Commerce', MIT Sloan Management Review (Summer): 54-62.

Magretta, Joan (1998): 'The Power of Virtual Integration: An Interview with Dell Computer's Michael Dell', Harvard Business Review, March-April

Magretta, Joan (2002): 'Why Business Models Matter', Harvard Business Review, May: 86-92. Magyarul megjelent: Magretta, Joan (2003) 'Miért fontosak az üzleti modellek?', Harvard Business manager, március-április: 26-33.

Mahadevan, B. (2000): 'Business Models for Internet-Baed E-Commerce: An Anatomy', California Management Review Vol. 42 (4): 55-69.

Makó Csaba-Móricz Péter-Illéssy Miklós (2003): Business Models in the Digital Value Chains: The Example of the TEDIP Regions, Research Report, TEDIP (Technology, Economics and Diversity in the Periphery) project, Budapest: MTA Szociológiai Kutatóintézet

Markides, Constantinos (1997): 'Strategic Innovation', Sloan Management Review 39(Spring): 9-23.

Markides, Constantinos (1998): 'Strategic Innovation in Established Companies', Sloan Management Review 40(Spring): 31-42.

McGahan, Anita (2004): 'How industries change', Harvard Business Review 82 (October): 87-94.

Móricz Péter - Drótos György (2006): 'Changing Structure and Identity of Virtual Organizations: The Case of the Hungarian Electronic Library'. EGOS Conference Paper, Bergen

Móricz Péter (2005): Az internetes üzleti modellek kritikai elemzése, $\mathrm{PhD}$ tézistervezet, BCE Gazdálkodástani $\mathrm{PhD}$ program 
Morris, Langdon (2003): 'Business Modell Warfare: The Strategy of Business Breakthroughs', White Paper, Ackoff Center for the Advancement of Systems Approaches

O'Daniel, Thomas (2001): 'A Value-added Model for eCommerce', Electronic Markets Vol. 11 (1): 37-43.

Osterwalder, Alexander - Yves Pigneur - Christopher L. Tucci (2005): 'Clarifying Business Models: Origins, Present, and Future of the Concept', Communications of AIS 15(May)

Osterwalder, Alexander (2004): The business model ontology. A proposition in a design science approach, These, Universite De Lausanne, Ecole Des Hautes Etudes Commerciales

Osterwalder, Alexander - Yves Pigneur (2002): 'An e-Business Model Ontology for modelling e-Business', 15th Bled Electronoc Commerce Conference. E-Reality: Constructing the e-Economy (June): 1-11.

Pateli, Adamantia (2002): 'Reviewing and Organising Research on Business Models (BMs)', The HERMES Newsletter by ELTRUN Issue 18 (October-November): $1-5$.

Pigneur, Yves (2002): 'A framework for defining e-business models', Brief Paper, 1-2.

Porter, Michael E. (1985): Competitive Advantage: Creating and Sustaining Superior Performance, New York: Free Press.

Porter, Michael E. (2001): 'Strategy and the Internet', Harvard Business Review, March: 63-78. Magyarul megjelent: Porter, Michael E. (2002) Stratégia és internet, Harvard Business manager, 2: 45-62.

Rappa, Michael (1999): 'Business models on the web', Course Material, downloaded from http://www.ecommerce.ncsu. edu/topics/models/models.html, 06/22/2003

Rayport, Jeffrey F. (1999): 'The Truth about Internet Business Models', Strategy + business Issue 16 (3): 1-3.
Rayport, Jeffrey F. - J. J. Sviokla (1995): 'Exploiting the Virtual Value Chain', Harvard Business Review 73(6) (Nov-Dec): 75-85.

Saban, Kenneth A. (2001): 'Strategic Preparedness: ACritical Requirement to Maximize E-commerce Investments', Electronic Markets Vol. 11 (1): 26-36.

Shoder, Detlef (2003): Geschäftsmodelle, EBM Präsentation, WHU Lehrstuhl für Electronic Business

Stähler, Patrick (2002): 'Business Models as an Unit of Analysis for Strategizing', Draft Working Paper.

Tapscott, Don (2001): 'Rethinking Strategy in a Networked World, (or Why Michael Porter is Wrong about the Internet)', Strategy+business, Issue 24 (Fall).

Tapscott, Don - David Ticoll - Alex Lowy (1999): 'Rise of the Business Web', Business 2.0, November: 198-207.

Tapscott, Don - Alex Lowy - David Ticoll eds. (1998): Blueprint to the Digital Economy. New York: McGrawHill

Timmers, Paul (1998): 'Business Models for Electronic Markets', Focus Theme Vol. 8 (2): 3-8.

Venkatraman, N. (2000): 'Five Steps to a Dot-Com Strategy: How To Find Your Footing on the Web', Sloan Management Review (Spring): 15-28.

Viscio, Albert J. - Bruce A. Pasternack (1996): 'Toward a New Business Model', Strategy + Business (2): 1-7.

Weill, Peter-Michael Vitale (2002): 'What IT Infrastructure Capabilities Are Needed To Implement E-Business Models?', MIS Quarterly Executive Vol. 1 (March): 17-34.

Werbach, Kevin (2000): 'Syndication: The Emering Model for Business in the Internet Era', Harvard Business Review (May-June): 84-93.

Cikk beérkezett: 2006. 11. hó

Lektori vélemény alapján átdolgozva: 2007. 2. hó

\section{E SZÁMUNK SZERZÖI}

Dr. Zilahy Gyula, egyetemi adjunktus, Budapesti Corvinus Egyetem, Móricz Péter, egyetemi tanársegéd, Budapesti Corvinus Egyetem, Csapó Krisztián, Ph. D. hallgató, Budapesti Corvinus Egyetem, Georgiu Achilles, informatikai menedzser, FlexiTon Kft., Fehér Judit, Ph,D. hallgató, Veszprémi Egyetem, Dr. Bencsik Andrea, egyetemi docens, Széchenyi István Egyetem, Győr 